\title{
The flip side of faculty status
}

\author{
By John Buschman \\ Information Services Librarian \\ Rider College Library
}

\section{The results of a regional survey of non-faculty librarians.}

1

he issue of faculty status for academic librarians has been thoroughly discussed, but it is a persistent theme that commands even weary attention. If for no other reason, faculty status needs to be looked at on a continuing basis so that new members of the profession know what the fuss is about. The publication of Krompart and DiFelice's "A Review of Faculty Status Surveys, 1971-1984"1 marks a turn in the nature of the discussion. Theirs is an effort to survey the published surveys in order to extract consistent findings and themes. The late arrival of this journal issue coincided with survey results being compiled by the author during the spring and summer of 1988 . There were important areas of overlap between Krompart and DiFelice and that survey.

Krompart and DiFelice note that the published surveys "have not been heavily cited nor have they otherwise received focused attention" (p. 14). Secondly, they make it clear that the surveys as a group will be used to reevaluate faculty status in light of the achievement of the goals of the ACRL Standards for Faculty Status (p. 14). They summarize this review noting "a working environment depressed in terms of stated goals, with practitioners often confused about what the profession and

'Janet Krompart and Clara DiFelice. "A Review of Faculty Status Surveys, 1971-1984," Journal of Academic Librarianship 13 (March 1987): 14-18. All page references in text refer to this article. their institutions expect of them.... The survey findings dramatize the need for careful consideration of what is worth preserving from traditional librarianship and gaining from faculty status" (pp. 17, 16). This article is based on comparison of results from Krompart and DiFelice's review of 14 years of data and a regional survey of non-faculty librarians. Any reevaluation of faculty status must take into account the professional climate on the other side of the fence. While the regional survey was small in scale, the results indicate areas of common ground. Further, the survey reached a specific population that Krompart and DiFelice noted were likely not to have faculty status, and it addressed a specific weakness in the surveys they reviewed. The balance of the paper will examine those areas of common ground: institutional variance, self-governance, compensation, and librarian comments, followed by a conclusion.

\section{Institutional variance}

"Librarians remain in what one research team over a decade ago termed 'academic limbo" ( $p$. 14). Librarians in older traditional institutions have had a particularly difficult time in achieving faculty status" and "Small private (especially religious) colleges are...more inclined to retain the traditional

\footnotetext{
${ }^{2}$ The author would like to acknowledge the reviewer who noted this point.
} 
terms of employment" (p. 16). Put another way, Krompart and DiFelice find that large public institutions are the most likely schools to be in line with the ACRL Standards. This particular group of schools, those not likely to comply with the Standards, was the target audience of the regional survey. One would expect to find in the results more than the usual variation in librarians' rank or status. This was the case, with some surprising additions.

When asked to identify groups of comparable rank or status on their campus, slightly over $40 \%$ of the respondents indicated none- a librarian-provided answer. Academic computing (39\%), academic counselors ( $28 \%)$, and development/alumni administration $(22 \%)$ were all prominent answers. This spread of identified equivalent groups shows a very wide variation in perceived rank and status. The "none" answer was most surprising since it was not provided, and could indicate a sense of professional isolation as a group.

Secondly, in reviewing the written comments solicited on the survey, an unusual situation occurred. Despite the attempt to eliminate from the group library staffs with faculty status (see Appendix 1), some did slip in. Of the 16 staffs surveyed, 9 had non-faculty status, 3 were split between faculty and non-faculty librarians, and 4 indicated a form of faculty status. These seven were included in the results for a variety of reasons. The areas of agreement between all responses were very strong. For instance, 14 librarians identified themselves as faculty in writing, but only 3 of them (obliquely) cited teaching faculty as their peers, and more than half of them noted equivalent groups other than the teaching faculty. Of the 4 staffs wholly comprised of faculty, 3 of them have the status without rank or tenure and similar conditions exist on the split staffs. These situations clearly add to the wide variety of campus environments that could have been discerned from the character of the group of institutions. Lastly, these 7 staffs were included in the mailing as a result of those institutions' lack of clarity in noting library faculty in their catalogs. The responses would indicate a form of faculty status for those librarians which could be said to be weak.

The issue was described as a "hodge-podge" on campus by one librarian, and the written comments illuminate some of the basic issues:

"Of the seven professionals on our staff, two have faculty rank. They have been here more than 17 years...We are now considered 'administrative staff,' and therefore, not entitled to raises, benefits, and privileges of faculty. We are not listed in the college bulletin this year.... In the past, we have been listed with the Groundskeeper! I kid you not!"

"We are classed as administrative staff, but are allowed to attend faculty meetings, but have no vote. Our status is indefinite."

\section{Self governance}

Krompart and DiFelice report that the area of the Standards dealing with governance was the most highly achieved by librarians: at least $75 \%$ were provided the opportunity to participate in university governance (p. 15). The regional survey results provide an interesting contrast to this finding. When asked how librarians' interests were represented on their campus, $34 \%$ indicated it was through a library committee, $20 \%$ through college/ university representation and $17 \%$ noted other similar kinds of forms. Similarly, when queried about involvement in campus-wide decisions, the answers were: representation in faculty/administrative governance $(34 \%)$ "other" mechanisms $(33 \%)$, and a library committee $(27 \%)$. Taken together, these results show a spread of some autonomous input.

However, these responses are overshadowed by the answer most prominent in both questions focusing on the library director. Eighty-eight percent responded that the director represented the librarians' interests on campus and $67 \%$ listed the director as the vehicle for involvement in campuswide decisions. None of the above responses came close to these and the spread in input would point to a weaker autonomy in the face of centralization of library "voice" and authority in the library director. One could assume that the director would remain important under any rank/status system, but the noted "limbo" in which these librarians operate could account for centralizing input in the person of the director. Again, librarians' comments illustrate the point:

"It is difficult to make our voices heard."

"Regardless of rank/status, librarians need to be members of standing committees so that (we) can keep abreast of campus and curricular changes and so that faculty and administration benefit from the various expertise available from the library."

"Because librarians have faculty rank and are not tenure track we are in a nebulous class. We do serve as representatives on some committees but for the most part ue are not clected. We are classified as administrators for some issues and are treated like faculty on others."

\section{Compensation}

At least $50 \%$ of the faculty status surveys indicated lower salaries for librarians than for teaching faculty. In their review of benefits, Krompart and DiFelice saw "widespread differences and confusion about these conditions of employment ...probably because the rights and responsibilities of teaching faculty are usually recognized as a traditional package...inextricably related....Some benefits, e.g., sabbaticals and research funds, were 
theoretically available to librarians, but it was not always clear if librarians, in practice, received these benefits" (p. 15)

While the results from the review of surveys are not terribly conclusive on the compensation benefits of faculty status, the librarians in the regional survey still perceived status and rank as an important issue $(83 \%)$. Thirty-nine percent indicated they were not under contract. When asked what their rank or status affected on their campus, $73 \%$ answered that it affected the faculty's perception and $64 \%$ noted it affected librarian salaries and benefits. The issue of status is still linked to professional relationships and standing, and in turn, with basic compensation issues. The written responses fill in more details:

"My position is considered an administrative position and promotions and raises are difficult to achieve. It would be easier if my position was faculty status; I could advance in rank through faculty promotion structure."

"The status of librarians changes as top administrators of the college change. We received faculty benefits, but work an administrative schedule."

"The one librarian who is tenured is low paid and has not advanced as fast as faculty hired at the same time."

\section{Librarian response}

One of the keys to the regional survey was to encourage written responses from the librarians. Of the faculty status surveys reviewed from 1981-1984, "only slightly more than 25 percent...queried librarians. [This] collection of survey responses lacks substantial information about what librarians experience and think. [There were] interesting results when librarian and director responses were compared" (p. 16). Sixty-seven percent of the returned regional surveys provided substantive comments and clarification. Those comments are an integral part of the results presented here. Additional to those previously given, the following represents all the areas written on in the responses.

Although directors were not a part of the survey group, two did take the trouble to copy the form and respond:

"We thankfully do not have a stratified campus. Of course, we are always concerned about salary equity, but the upper administration does try to be fair."

"We will be studying this issue [librarians rank/ status] carefully next year."

As Krompart and DiFelice noted, responses from librarians at the same institution did not entirely agree with the first director. The second comment struck a chord. That was the third institution considering a ranking structure for librarians.
Given that so many librarians believed in the importance of the issue, this is perhaps not a surprise.

The variations of status and personnel issues brought the most responses in attempts to explain local situations. The following is very typical of seven other responses:

"Librarians can vote at faculty meetings and sit on faculty committees but they do not have academic rank, tenure, or a nine-month contract."

There were five responses similar to this explanation:

"There is nothing really comparable. We have too many exceptions and perversions of the usual categories....All librarians are lumped into a category which is euphemistically called 'administrative, 'but the actual meaning of the terms will differ between the library and other units and within units."

Still others delineated the terms of employment as non-faculty:

"[Giving 'Administration' as the group of comparable rank/status, it was suggested that $]$ some are 'more equal' than others. Personnel on campus has been ad hoc, aprofessional."

"The perception of librarians as faculty/administration changes from one administration to another. Librarians receive faculty benefits, but work an eleven-month contract like administrative offices."

A few took the pains to explain the source of both non-faculty and faculty librarians within their staffs:

"I was the last librarian hired at a faculty rank. The person hired after me was not given a choice and was hired as Professional Staff. We are trying to get this changed."

"I am the first non-faculty librarian to be hired at the library. Our director was firmly opposed to faculty status. There are five who currently hold faculty status and one, me, who is considered professional staff."

The issues of compensation were addressed very specifically in some of the responses:

"Librarians have a 12-month contract as opposed to a 10-month contract which the teaching faculty has. I feel, therefore, that some monetary compensation should be available to librarians as teaching faculty can earn extra money by teaching during the summer and this is not possible for librarians."

"This is the first year that I will be paid under administrative staff. In the past, I have always been paid according to faculty raises. I am formally complainingabout this, this afternoon, but expect to get nowhere."

In contrast to movement in three libraries to create ranking and promotion structures for librarians, there seemed to be other movements afoot in the opposite direction: 
"The university administration is, I suspect, highly interested in controlling what it sees as an educated proletariat (librarians, computer center staff, etc.) and it is, I believe, trying to move us into the administrative corral."

"We are currently undergoing a change in status; it is subtle but still present. Our current director and the administration would like, it seems, to have us more closely aligned in status, etc. with the administrative arm of the University, rather than the faculty. At present the director of libraries is an administrator, while other librarians are still allowed to vote in faculty meetings and serve on university committees. We are beginning to see this 'benefit' erode as our presence on certain committees is now being questioned. This issue is complex, but our status seems to be slowly eroding toward that of 'administrators' rather than 'faculty. 'We do not receive 'tenure, 'but rather 'continuing appointment."

Finally, there was not universal agreement that this issue was important. Eleven percent said it was not and $16 \%$ said it affected nothing on their campus. Dissent took different forms:

"In the library, we simply have no time to be on a tenure track. The faculty rank/status issue is an ambiguous one and seems to make little actual difference in how librarians are treated."

"Our hybrid works very well for us and our status, salary, benefits, etc., are comparable to other academic librarians in our area....As you might imagine, evaluations are tricky. However, we have to date managed to survive and have a good relationship with the other faculty and the administration and good morale in-house."

"We are not tenurable and do not have faculty ranks. Some would say there would be disadvantages, such as the need to participate in scholarly activities. To my mind this is not a disadvantage, just a responsibility."

"We have faculty status, but are non-tenured-a comfortable compromise."

\section{Conclusion}

Krompart and DiFelice do not paint a rosy picture of the long-term success of faculty status so far. Some evaluations of the regional survey results have been offered, but those individual pieces do not give an overview of the situation. Put together, they form a picture that is perhaps more bleak: non-faculty librarians would find themselves allied with the professionals who work in the administrative offices of their institution. Those offices typically are under administrative direction and do not have autonomy to act or participate in institutional self governance. The alternative to this alliance is the perceived lack of peers or allies within the college/university system. Personnel and promo- tion systems would be largely unclear and based on prevailing ideas in library and college/university administration. They would shift over time. Participation in self governance would be largely ineffective, where available. For the most part, effective action on behalf of both librarians and the library would be centered in the library director leaving the professional environment dependent on this administrator. Because of ad hoc and shifting policies as well as a lack of clear perceptions about the status of librarians, salaries would lag behind teaching faculty and perhaps be based on clerical staff or "administration" raises. The cumulative effect of this would leave the librarian isolated within the library; without a context from which to build the necessary credibility and power base to change these policies (and practices) and gain equity and voice on their campus, or even a professional context for growth.

While the preceding is a pessimistic reading of the results, it does not stray from them. The variety of status situations is startling and the prominent response that there were no other peer groups around was perhaps most troubling of all. Status and ranking, and compensation issues vary and shift with administrators and they seem to lack reasoning (none were reported by the librarians). They result in inequities, split staffs, and no real structures in place to challenge the results. Many librarians do not even have contracts. Incentive structures for raises and promotions are probably minimal (the survey did not contain a question on this, but should have as a logical link to the contract question). All of this comes out in the results and comments.

In sum, while Krompart and DiFelice find faculty librarians not fully achieving the stated goals of the ACRL Standards, the situation for the librarians in this survey is at least as bad. Perhaps the key to this is that while faculty librarians may not yet fully participate in the privileges due to them, they have the crucial elements of context and allies (teaching faculty as peers), professional structure (tenure and promotion), and the right to participate in institutional governance. Any one of these is difficult to build without the other two. There seem to exist few well-developed alternatives to faculty status like the one at Dickinson College. ${ }^{3}$ Any reevaluation must account for these weaknesses and problems, as well as those problems with faculty status. In the long run, the decision will need to be made about which alternative contains the most potential to successfully adapt and achieve the

${ }^{3}$ Joan M. Bechtel, "Academic Professional Status: An Alternative for Librarians," Journal of Academic Librarianship 11 (November 1985): 289-92. 
spirit, if not the letter, of the ACRL Standards for Faculty Status. Many of the rights and privileges of the faculty librarian would be difficult to build or replace outside of that context.

Author's Note: The author would like to thank Ene Andrilli and Rebecca Reilly for their help with this project.
A list of the institutions involved in the survey, along with methodological notes and tabulated survey results, may be obtained by sending an SASE to: John Buschman, Rider College Library, 2083 Lawrenceville Rd., Lawrenceville, NJ 086483099 .

\section{Hearings to be held on standards for faculty status}

The ACRL Academic Status Committee is charged with reviewing and updating the standards, guidelines, and related documents that pertain to faculty status and academic governance. The Committee will hold the first of two open hearings on the Standards for Faculty Status for College and University Librarians document at the 1990 ALA Midwinter Meeting in Chicago. These hearings are a unique opportunity for the membership to comment upon this important statement before the Committee begins its deliberations. The Midwinter hearing will be held on Sunday, January 7, 9:00-11:00 a.m.

The Standards for Faculty Status for College and University Librarians document was adopted on June 26, 1971. In the almost two decades that have passed since then, it has not been revised, although many changes have taken place in college and university libraries. For example, the move toward participatory governance, which has characterized this period, does not seem to have strengthened the bid of academic librarians for faculty status. In fact, it appears that there may be fewer institutions that grant librarians faculty status today than there were in 1971 .

The Standard as it is now written follows:

\section{Standards for faculty status for college and university librarians}

In order to recognize formally the college or university librarian's academic status, the Association of College and Research Libraries and the American Library Association endorse, and urge all institutions of higher education and their governing bodies to adopt, the following standards for all academic librarians:

1. Professional responsibilities and self determination. Each librarian should be assigned general responsibilities within his particular area of competence. He should have maximum possible latitude in fulfilling these responsibilities. However, the degree to which he has fulfilled them should be regularly and rigorously reviewed. A necessary element of this review must be appraisal by a committee of peers who have access to all available evidence.

2. Library governance. College and university libraries should adopt an academic form of governance. The librarians should form as a library faculty whose role and authority is similar to that of the faculties of a college or the faculty of a school or a department.

3. College and university governance. L ibrarians should be eligible for membership in the academic senate or equivalent body at their college or university on the same basis as other faculty.

4. Compensation. The salary scale for librarians should be the same as that for other academic categories with equivalent education and experience. Librarians should normally be appointed for the academic year. If a librarian is expected to work through the summer session, his salary scale should be adjusted similarly to the summer session scale of other faculty at his college or university.

5. Tenure. Librarians should be covered by tenure provisions the same as those of other faculty. In the pretenure period, librarians should be covered by written contracts or agreements the same as those of other faculty.

6. Promotion. Librarians should be promoted through the ranks and steps on the basis of their academic proficiency and professional effectiveness. A peer review system similar to that used by other faculty is the primary basis of judgment in the promotion process for academic librarians. The librarians' promotion ladder should have the same titles, ranks, and steps as that of other faculty.

7. Leaves. Sabbatical and other research leaves should be available to librarians on the same basis, and with the same requirements, as they are available to other faculty.

8. Research funds. Librarians should have access to funding for research projects on the same basis as other faculty.

9. Academic freedom. Librarians in colleges and 